\title{
Web-based problem-based collaborative learning for converted muslim in learning islamic knowledge
}

\author{
Nurul Fatihah Sahidan, Nazrul Azha Mohamed Shaari, Hayati Abd Rahman \\ Faculty of Computer and Mathematical Sciences, Universiti Teknologi MARA, Malaysia
}

\begin{abstract}
Article Info
Article history:

Received Jan 11, 2019

Revised Apr 6, 2019

Accepted May 15, 2019

\section{Keywords:}

Collaborative learning

Converted Muslim

Islamic knowledge

Problem-based technique

Web-based learning

ABSTRACT

Web-based collaborative learning is well accepted learning methods since it provides flexibilities not only in term of learners' interaction but also its timeliness learning materials. Even though there are many websites offer learning materials for Muslims generally but for new converted Muslims getting authentic materials and proper guidance are complicated. Hence, a web-based problem-based collaborative learning is proposed. This method integrates an elected virtual instructor to facilitate and support the new converted Muslims' cognitive and emotional activities, develop their confidence of resolving and dealing with problems they are facing. This paper relates and analyzes the problem-based collaborative learning in terms of the functionality and user acceptance. Based on a survey conducted, it shows that $85 \%$ of the respondents found the system very useful and easy to use while $80 \%$ found that the system met their requirements. This system hypothetically able to help, and ease new converted Muslims in exploring Islamic authentic knowledge by using problem-based technique in web-based collaborative learning.
\end{abstract}

\section{Corresponding Author:}

Nazrul Azha Mohamed Shaari,

Faculty of Computer and Mathematical Sciences,

Universiti Teknologi MARA,

Shah Alam, Selangor, Malaysia.

Email: nask@tmsk.uitm.edu.my

\section{INTRODUCTION}

Web based learning becoming popular since it provides varieties of learning materials such as science and technology, Islamic education etc. This development allowed users to access more useful learning materials for their benefits at their own pace [1]. Since learning Islamic education demand voluntary and high-level motivation from learners, thus it requires instructors. Even though there are many websites and blogs have created for converted Muslims as their reference but those type of resources are confusing [2]. Moreover, according to Shaharuddin (2016) getting authentic material in teaching Islamic Education for converted Muslim is almost nonexistence. According to Amir (2015), the approach and material for teaching fundamentals Islam for new converted Muslim must be developed based on the level of their knowledge towards Islam as there are new Muslim.

In this sophisticated modern era, efforts in developing da'wah becoming easier with the existing variety of platform such as personal blog, web-based learning [3], collaborative learning [4], social media [5] etc. However, not all the resources about Islam posted are authentic. Moreover, with the advancement of technology today, a lot of information, whether authentic or confusing is rapidly dispersed [2].

Based on preliminary interviews conducted during the study, the main problem faced by new converted Muslim is they face difficulty in getting help from knowledgeable instructors [6]. Both parties can only meet up for discussions for a short while since their time is limited. As a result, many of new converted 
Muslim decided to explore on Islam from websites and blogs that display unverified information, contradicts opinions [7] and misleading issues such as converted Muslim must become a Malay after they have converted into Islam. They also claimed that there are instructors whom are not helpful in guiding them on learning and understanding Islam properly. In a way, those issues contribute in making the quality of Islamic education among new converted Muslim to the level that can be proud of [8]. As a new comer in a new territory of life, a new converted Muslim deservedly need to be guided and supported, especially their affection aspect. They need a place that they can shoulder on at any time.

Collaborative learning is an educational approach that involve teachers and students working together to discuss or solve a given task [1]. They engage deeply where member of the group asks among themselves for information, evaluate ideas, and monitor each other work. They treat information as model that can be created and shared in a group where members actively interact by sharing experience [9]. As a result, a quite a number of web-based learning apply this approach. While web-based collaborative learning in Islamic education for new converted Muslim take a step ahead where problems-based technique is also incorporated into it [10].

In Malaysia, the numbers of converted had been increased and the amount of the increment is greater than what is statistically reported by the Islamic Religious Department. According to Prof Madya Dr Razaleigh Muhamad@Kawangit, Head of JPDK Department, in their research findings done by the Department of Islamic Studies and Leadership (JPDK), Faculty of Islamic Studies, Universiti Kebangsaan Malaysia (UKM), it was found that many converted Muslims are not registered with the Islamic Religious Department for a few reasons [11]. This study only focuses only on the aspects of the collaboration between converted Muslims and authentic scholars on learning Islamic knowledge based on technology of web. For now, simple and yet important functions of web-based learning features is developed and will be upgraded gradually. Users of this system only for identified Islamic learning instructors and members from Persatuan Saudara Baru, an organization in Malaysia.

This paper presents web-based problem-based collaborative learning for converted Muslim in learning Islamic knowledge. In this research, findings and results from the survey has been conducted. Survey has been conducted to analyze the functionality and user acceptance towards the system. Results shown that $85 \%$ respondents found the system very useful and easy to use while $80 \%$ found the system met it requirements.

\section{RESEARCH METHOD}

This section provides an overview of the project, which consists of a literature review on converted Muslim, Islamic education, collaborative learning techniques, and related web-based applications.

\subsection{Converted muslim}

Converted Muslim is referred as individual of non-Muslim who are new to Islam and thus their faith in adapting the new life need to be supported and strengthened from their Muslims brother and sisters. In fact in Islam, individuals who embrace Islam or customary called as Muallaf [12], are considered as siblings and need to be defended until they are ready to be independent, especially in religious matters such as Aqidah and Ibadah- purifying concepts, prayer, fasting etc. [13]. The Islamic Development of Malaysia (JAKIM), affirmed that the maximum period for a new convert to be called as a Muallaf was set for five years [14].

\subsection{Islamic knowledge}

Islamic education is aimed at forming a complete Muslim, developing all human potentials both physically and spiritually, to develop the harmonious relationship of everyone with God, man, and universe [10]. Thus, Islamic education is very different from other religious education whether in theory as well as practical since it's based on Al-Quran and Hadith or Sunnah. These two books of reference provide guidance of life for Muslims especially in creating harmony in life. Apart from that, Islamic educational theory earned to actualize and to make perfect human dimensions. In Islam, Muslims are also urged to move forward in life and hence doing research especially in the field of science and technology is well encouraged. With the rapid development of technology of web, learning religious knowledge which is very personal to its believers is easy nowadays. It does not require special physical places anymore such as mosque or school. However, the implementation of web-based learning for Islamic education must be cautioned because it has big impacts on the learner who are novice in the world of Islam.

\subsection{Collaborative learning technique}

Collaborative learning encourages learners to interact between them actively [15]. Learners can also share knowledge [16] and create new information [17]. Communication and interaction among learners allow collaborative learning elements focusing on synchronous and asynchronous tools during collaborative 
learning [18]. There are several techniques in collaborative learning such as problem-based [19], fishbowl [20], jigsaw [16] and think-pair-share [18]. In this study, collaborative learning technique that will be used is problem-based technique.

\subsubsection{Problem-based technique}

Problem-based Technique Problem-based technique is when practical problems occurs based on the real situation with multiple solutions of doing it [21] and thus become their new knowledge. Learners will work on teams to define the problem and find out a solution out of it. Learners must apply the knowledge and information they gained from their research for problem solving and share the results of their findings. Islamic instructor will guide the users by answering the member's questions and monitoring the group discussion. Real world problems is vital as it can be used to encourage learners in identifying the concepts so that they can solve the problems. Learners also work in teams, as a result they will able to absorb collaborative skill in communicating, receiving and merging the information. With the use of problem-based technique, learners are expected capable of thinking critically, investigating, analyzing and using relevant resources for learning, collaborating with others and using the knowledge given as reference in their daily life [22].

\subsubsection{Fishbowl technique}

Fishbowl is a discussion format in which most of the class members form a circle around them and then begin their group discussion [21]. Basically, discussions take place among two group - inner or fishbowl and outer group or observers. Instructor triggers the discussion by giving the inner group some topics while the outer group observe the process. The discussion engages participants in active listening, active communicating and increase understanding from multiple viewpoints. It is a method for respectful and equal communication. It is also provide chances to study and discover about social interaction [23].

\subsubsection{Jigsaw technique}

In terms of group formation jigsaw technique is unique and more complex. Learning takes place in a group, named as home group and expert group [24]. The home group is responsible to each member in the group and discuss in general on the selected materials while the expert group study on more specific materials. This type of collaborative learning model encourages students to remember and understand more on the subject matter [22].

\subsubsection{Think-pair-share technique}

Think-pair-share technique more to discussion and sharing information [25]. The purpose of this technique is to encourage learners by allowing them to interact with other collaborators and sharing knowledge that leads to new information among them. This technique is an active learning strategy in collaborative learning theory [18].

\subsection{Comparison of collaborative learning technique}

Table 1 show the comparison of collaborative learning technique has been made. In this project, collaborative learning technique that has been used is problem-based technique. Problem-based technique is when practical problems occurs that are based on the real situations [21]. Target users in this project will faces a real problem on their situation before they receive a new knowledge. This technique fits well with the project since the learners want to find out problem they are facing in real life. Users which are instructors and members will work on teams to define the problem and find out a solution or answer for the problem faced. Users must apply the knowledge and information they gained from their research for problem solving and share the results of their findings. Islamic instructor will guide the users by answering the member's questions and monitoring the group discussion. By using problem-based technique, learners be able to manage the question and think critically. Learners be able to investigate, analyze and use relevant resources for learning purpose. The significant part is learners be able to collaborate with other users and use the knowledge given as reference in daily life.

\subsection{Existing system}

Existing system provided some information about Islam, but it is not specific for converted Muslim and it is difficult for them to ask question. However, these websites may also be used as a guideline to get some idea in developing the product.

\subsubsection{JAKIM}

JAKIM is one of the existing systems where it can be seen as one quite complete portal for Muslims in Malaysia but there is no discussion feature and is not specific site for Muallaf to refer to or ask question. 
Basically, this system is very informational as it only shows the current news and issues about international conference, classes, lectures, journals, articles and etc. Although this portal contains a lot of information, however, this information is rarely updated.

Table 1. Comparison of collaborative learning technique

\begin{tabular}{|c|c|c|c|c|c|}
\hline \multicolumn{2}{|l|}{ Component } & Problem-based & Fishbowl & Jigsaw & Think-pair-share \\
\hline \multicolumn{2}{|c|}{ Real situation problem } & 1 & & & \\
\hline \multicolumn{2}{|c|}{ Assigning the problem } & & I & l & I \\
\hline \multicolumn{2}{|c|}{ Develop Critical- think skill } & I & & & \\
\hline \multirow{4}{*}{ Thinking activity } & Analyzing & I & & & \\
\hline & Evaluating & I & & I & ( \\
\hline & Contribution & I & & I & 1 \\
\hline & Individually & & & & I \\
\hline \multirow[t]{2}{*}{ Group formation } & Home group & & I & l & I \\
\hline & Expert group & I & I & I & I \\
\hline Discussion & & I & I & I & I \\
\hline Social interaction & & I & I & & I \\
\hline collaboration & & I & I & I & I \\
\hline Active learning & & & I & & I \\
\hline
\end{tabular}

\subsubsection{PERKIM}

The next existing system is perkim.net.my. Where is manage by, Pertubuhan Kebajikan Islam Malaysia (PERKIM). This system is also very informational as it only shows the current news and issues about politics, donations towards Muallaf, and etc. This website has forum feature where only contains about the activities of the organization. There is no discussion related to education in this forum.

\subsubsection{IslamGRID}

IslamGRID website is has information about Islamic education such as "Aqidah", "Ibadah", "Akhlak" and etc. However, this website does not have any discussion feature that allow users to ask question and it does not have any update since 2014. In addition, there are several links are not functioning.

\subsubsection{JAWHAR}

This system is very attractive and good use of colors. It also has mobile version and already published at Google play. However, JAWHAR only focused on Wakaf, Zakat and Hajj procedure. Information and knowledge needed for converted Muslim is not provided for information and knowledge.

\subsection{Comparison of existing system}

Table 2 show the comparison of existing systems and the features that has been implemented in this project. Features that has been implemented in Web-based Problem-based Collaborative Learning for Converted Muslim in Islamic Knowledge is dashboard, forum page, frequently question, instructor guidance, Islamic learning, live video, live chat, comment rate and visitor statistic. Collaboration between members and instructors will occur more in forum, Islamic learning and live video. Collaboration between instructors also can be made in forum page without members contribution. In forum page, members can post a new topic or question that can be discuss with instructors and other members. In Islamic learning page, instructor can post a new learning topic and members are allowing to comment or ask a question. New topic that will be post by instructor will be discuss first among instructors. Instructors will use forum for instructor or face to face discussion as a mechanism to determine the authentication of resources. In live video page, service may allow real time point to point communications as multicast communication from one user to many users. It offers text-based messages, voice and video chat to be shared simultaneously. Live chat will help users to find their problems. Live chat is very useful for new visitor of website. Statistic of visitor will be recorded to track number of users visit the website. Comment rate function is to view comment that get the highest rank in a certain topic. The mechanism used for authenticity of resources is discussion among qualified instructors. The purpose of discussion is to determine the authenticity of resources before it posts into the web system. 


\begin{tabular}{|c|c|c|c|c|c|}
\hline System Feature & JAKIM & PERKIM & IslamGrid & JAWHAR & $\begin{array}{c}\text { Web-based Problem-based Collaborative } \\
\text { Learning for Converted Muslim in } \\
\text { Learning Islamic Knowledge }\end{array}$ \\
\hline Dashboard & / & / & / & / & 1 \\
\hline Forum & & l & & & l \\
\hline FAQ & / & I & & & / \\
\hline Instructor guidance & & & & & l \\
\hline Islamic Learning & / & & / & & l \\
\hline Live video & & & & & l \\
\hline Visitor statistic & & & & & I \\
\hline Comment rating & & & & & l \\
\hline Live chat & & & & & / \\
\hline Resource Authenticity & l & & l & & I \\
\hline
\end{tabular}

\section{RESULTS AND DISCUSSION}

The convenient model for this project development is ADDIE Model because the techniques are acceptable, and it will be used in the project development. There are 5 phases of ADDIE model which is analysis, design, development, implementation and evaluation.

\subsection{Phase 1: Analysis}

In this phase, second interview has been conducted to one of members of Persatuan Saudara Baru, literature review that were made on converted Muslim, Islamic education, collaborative technique and existing system.

The third interviewee a member of Persatuan Saudara Baru. Based on interview that has been conducted, class runs on Saturday and at midnight only. Respondent also mentioned that, most of the members are came from other state such as Malacca and Negeri Sembilan. It quite far for members to attend the class because this class located in Selangor. Hence, respondent has mentioned about a website that was specifically for converted Muslim but other Muslims also can join. This website will able to teach converted Muslim about Islam from scratch since converted Muslim are new in Islam [17]. Therefore, Web-based Problem-based Collaborative Learning for Converted Muslim in Islamic Knowledge has been proposed to the respondent. This website will ease the discussion and learning process between converted Muslim and Islamic instructors. Collaboration between users will occur by using this platform

\subsection{Phase 2: Design}

Second phase in the ADDIE model is design phase. The information that has been collected in analysis phase will proceed to the design phase. In this phase, user interface of the system on the collaborative parts are proposed. Figure 1 shows interface of web-based collaborative learning for user interface on forum page. This page allows users to discuss among them. The arrangement neat and follow the track of post. It contains all the details that accessible for users' understanding. Figure 2 shows interface of web-based collaborative learning on I-Learn page. This page consists of list of topics that post by admin and instructor. The design is simple and easy to understand. Figure 3 shows interface design of web-based collaborative learning for user interface on GoLive page. GoLive page allows admin and instructor to teach members face to face.

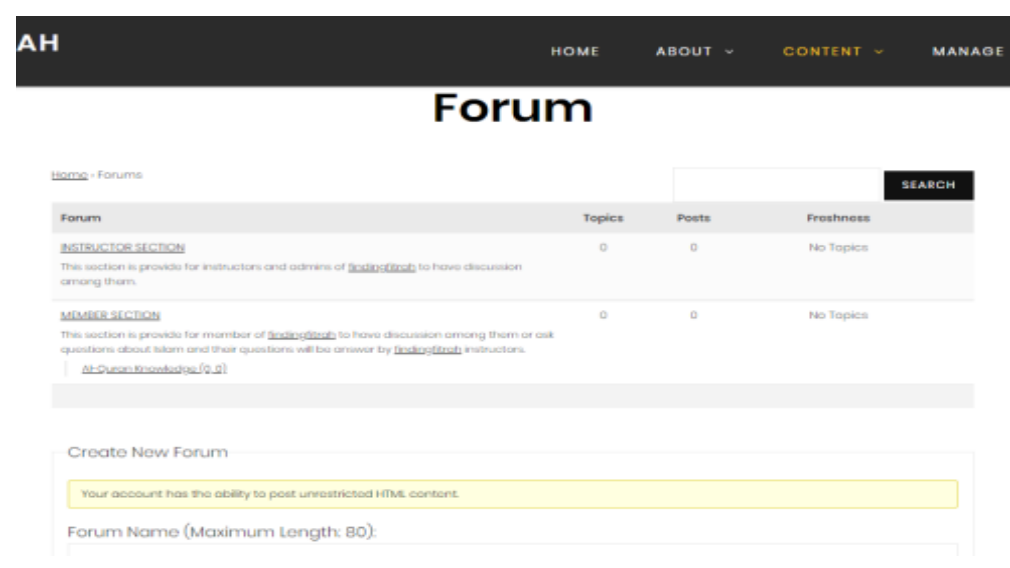

Figure 1. Forum page 
-Learn

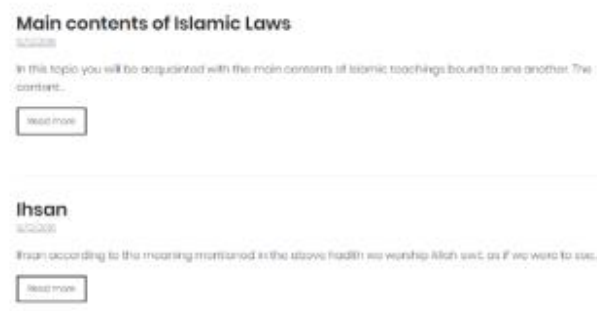

Figure 2. I-Learn page

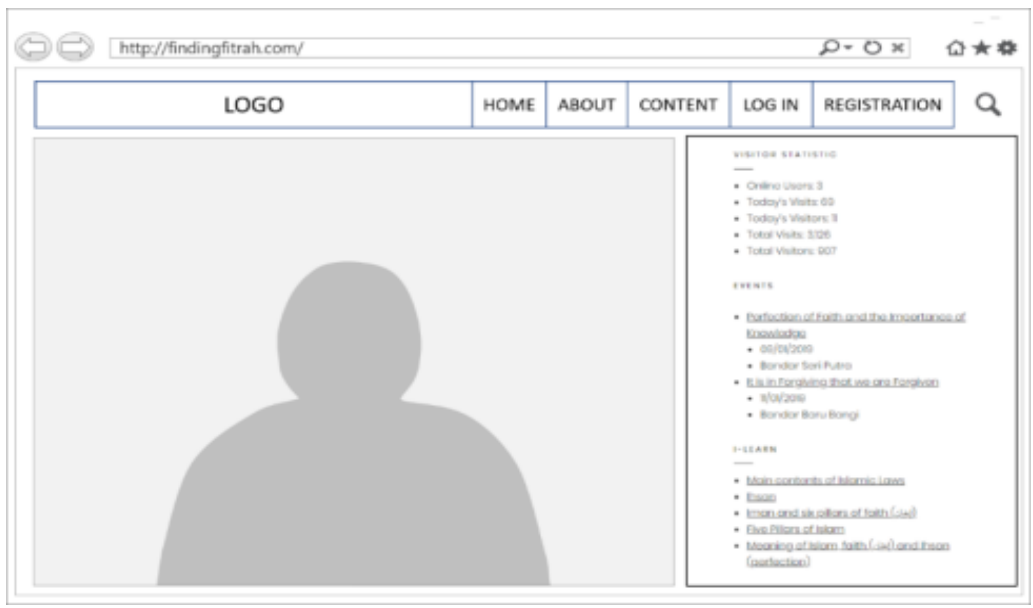

Figure 3. GoLive page

\section{FINDING AND RESULT}

A set of questionnaires has been distributed to 20 Muslim respondents in varies races and the questions consist of two sections. Respondents were required to answer the questions based on their perception. In first section, users need to answer the demographic information. Second section is about the functionality and user acceptance towards web system. Based on survey result in Table 3, male respondent is $65 \%$ higher than female respondent which is $35 \%$. Respondent who are aged 50 above score $65 \%$ which is higher than others aged group. Chinese Muslim has the highest respondents in this survey which is $45 \%$. The highest level of education is in degree level with $70 \%$.

Table 3. Respondent demographic

\begin{tabular}{cccc}
\hline \multicolumn{2}{c}{ Demographic } & Respondent & Percentage (\%) \\
\hline \multirow{2}{*}{ Gender } & Male & 13 & 65 \\
& Female & 7 & 35 \\
Age & $20-30$ & 3 & 15 \\
& $40-50$ & 4 & 20 \\
& 50 above & 13 & 65 \\
Race & Bumiputra & 7 & 35 \\
& Chinese & 9 & 45 \\
Education & Indian & 4 & 20 \\
Level & SPM & 2 & 10 \\
& Degree & 14 & 70 \\
\hline
\end{tabular}

Based on the survey result in section 2 refer Figure 4, 65\% respondents feel that the interface design is attractive. $80 \%$ respondents voted that the website is clean and has simple presentation. $95 \%$ of respondents satisfied that the organization of information on the website is clear. Next, all participants vote that the website

Web-based problem-based collaborative learning for converted muslim in... (Nurul Fatihah Sahidan) 
is easy to use and user friendly. $95 \%$ participants believe that the website is easy to navigate, and $85 \%$ participants agreed that the website is responsive. For the most significant find is $85 \%$ participants found the website is very useful and easy to learn, $80 \%$ participants found the system met the requirements and $75 \%$ participants agreed that the system responded in a consistent and predictable way it should be. Overall, majority of participants satisfied with the website.

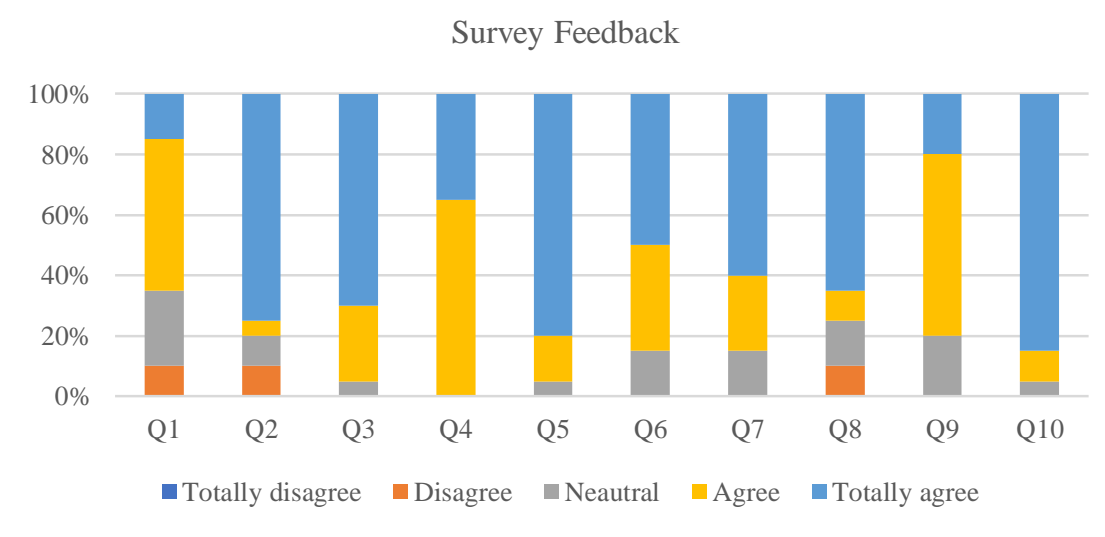

Figure 4. Shows the user feedback of the system in section 2

\section{CONCLUSION}

This paper discusses on the project of the web-based collaborative learning which is created as a platform for converted Muslim and other Muslim as well to collaborate with instructors to get an authenticity of resources. This project is develop based on the objective which is to design a web-based collaborative learning in Islamic education, to develop a platform that help converted Muslim get authentic information about Islam and to evaluate the functionality and user acceptance test of Web-based Problem-based Collaborative Learning for Converted Muslim in Islamic Knowledge. Literature review, comparison existing system and interview has been done in gathering information. Survey has been conducted to the target user which is converted Muslim. This system supposedly helps converted Muslim and ease their learning in Islamic education. Collaborative learning method is meant to make learning more exciting when users become active participant.

\section{ACKNOWLEDGEMENTS}

This work was supported by the project 600-IRMI/PERDANA 5/3 BESTARI (097/2018). Design and Development on Interactive Digital Story About Good Moral Value Based on Malaysia Culture, funding from the Institute of Research Management \& Innovation (IRMI), University Teknologi MARA (UiTM).

\section{REFERENCES}

[1] Cao, S., "A Hybrid Collaborative Filtering Recommendation Algorithm for Web- based," Behavioral, Economic and Socio-cultural Computing (BESC) International Conference, pp. 168 - 171, 2015.

[2] Kamsin, A., et al., "Program for Developing the Novel Quran and Hadith Authentication System," International Journal on Islamic Applications in Computer Science and Technology, vol. 3, pp. 8-17, 2015.

[3] Afolaranmi, S., el at., "Providing an Access Control layer to Web-Based Applications for the industrial domain," IEEE Conference Publications, pp. 1096-1102, 2017.

[4] Molenaar, I., el at., "Dissecting sequences of regulation and cognition: Statistical discourse analysis of primary school children's collaborative learning," Metacognition and Learning, 9(2), pp. 137-160, 2014.

[5] Caballe, S., el at., "A Methodological Approach to Provide Effective Web-Based Training by Using Collaborative Learning and Social Networks," 2014 Eighth International Conference on Complex, Intelligent and Software Intensive Systems, pp. 64-71, 2014.

[6] Abdullah, MA, "Personal interview," October 2017.

[7] Abdullah, J, "Personal interview," October 2017.

[8] Shaharuddin, S. A., et al., "Isu Dan Permasalahan Mualaf (Cina) Di Malaysia," International Conference on Aqidah, Dakwah And Syariah 2016 (Irsyad 2016), 2016. 
[9] Chiu, M. M., "Effects of argumentation on group micro-creativity: Statistical discourse analyses of algebra students' collaborative problem solving," Contemporary Educational Psychology, vol. 33, pp. 382-402, 2008.

[10] Ali, K. M., "Integritas Pendidikan Agama Islam Terhadap Ilmu Pengetahuan Dan Teknologi," pp. 1-14, 2016.

[11] Amir, A., "Bilangan Mualaf Di Malaysia Lebih Ramai Daripada Catatan Rasmi," Retrieved from Universiti Kebangsaan Malaysia: http://www.ukm.my/news/Latest_News/bilangan-mualaf-di-malaysia-lebih-ramai-daripadacatatan-rasmi/, May 2015.

[12] Azman, A. I., "Indeks Pengukuran Penentuan Had Tempoh Mualaf di Malaysia," Journal of Fatwa Management and Research (JFMR), pp. 40-63, 2015.

[13] Subri, I. M., "Penerimaan Penggunaan Istilah Mualaf dalam Kalangan Mualaf di Malaysia," Journal of Fatwa Management and Research, pp. 111-134, 2015.

[14] Malaysiakini, "Jakim: Had maksimum panggil 'mualaf' 5 tahun," Retrieved from malaysia kini: https://www.malaysiakini.com/news/327756, January 2016.

[15] Shawky, D., el at., "Affordances of computer-supported collaborative learning platforms: A systematic review," In Proceedings of 2014 International Conference on Interactive Collaborative Learning, ICL 2014, pp. 633-651, 2014.

[16] Ghorashi, S. and Jensen, C., "Jimbo: A Collaborative IDE with Live Preview," 2016 9th International Workshop on Cooperative and Human Aspects of Software Engineering, p.4, 2016.

[17] Jati, N., "Personal Interview," 13 December 2017.

[18] San Tint, S. and Nyunt, E. E., "Collaborative Learning with Think -Pair - Share Technique," Computer Applications: An International Journal (CAIJ), vol. 2(1), pp. 1-11, 2015.

[19] Unal, C., el at., "Flipped Classroom with Problem Based Activities: Exploring Self-regulated," Journal of Educational Technology \& Society is available under Creative Commons, 20(1), pp. 337-349, 2019.

[20] Yishay, M., el at., "Practical Patterns for Active and Collaborative MOOCs: Checkpoints, FishBowl and See Do Share," Design Patterns for Open Online Teaching and Learning, pp. 48-53, 2015.

[21] Davidson, N. and Major, C. H., "Boundary Crossings: Cooperative Learning, Collaborative Learning, and ProblemBased Learning," Journal on Excellence in College Teaching, vol. 25, pp. 7-55, 2014.

[22] Saputra, M., el at., "Developing Critical-Thinking Skills through the Collaboration of Jigsaw Model with Problem-Based Learning Model," International Journal of Instruction, pp. 1078-1094, 2019.

[23] Effendi, A., "The Effectiveness Of Fishbowl Technique Towards Students' Self Efficacy In Speaking," Journal of Languages and Language Teaching, pp. 7-55, 2017.

[24] Sulisworo, D, el at., "The Development of Mobile Learning Application using Jigsaw Technique," International Journal of Interactive Mobile Technologies (iJIM), vol. 10(3), pp. 11, 2016.

[25] Khotiyal, A., "Think-Pair-Share in a Large CS1 Class: Does Learning Really Happen?", Innovation and Technology in Computer Science Education (ITiCSE), pp.51-56, 2014.

\section{BIOGRAPHIES OF AUTHORS}

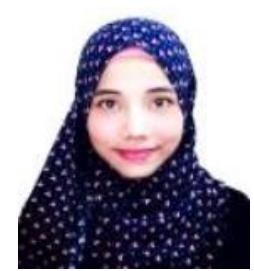

Nurul Fatihah Sahidan is a master's student in Master Computer Science (Web Technology) at University Teknologi MARA, Shah Alam, Selangor, Malaysia. She is currently in her final year. Her area of interests is Web-based Technology, Big data, Image Processing and Multimedia Computing.

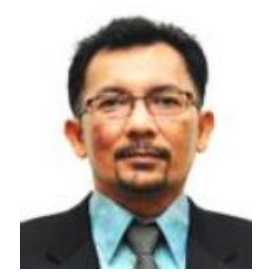

Nazrul Azha Mohamed Shaari (Dr.) is a PhD holder in Information Science at University Kebangsaan Malaysia, Bangi, Selangor, Malaysia. He is currently a senior lecturer at University Teknologi MARA, Shah Alam, Selangor, Malaysia. His area of interests is Virtual Reality and Multimedia

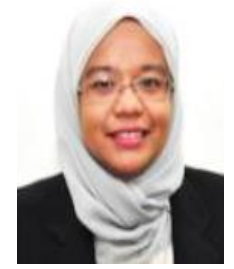

Hayati Abd Rahman (Dr.) is a PhD holder in Information Science at University Kebangsaan Malaysia, Bangi, Selangor, Malaysia. She is currently a senior lecturer at University Teknologi MARA, Shah Alam, Selangor, Malaysia. Her area of interests is Information Retrieval, Semantic/Linguistic Computing and Multimedia. 